\title{
TEACHER'S METHODICAL ACTIVITY AS A SOURCE OF EDUCATIONAL AND METHODICAL TASKS ${ }^{1}$
}

\author{
SVITLANA SKVORTSOVA
}

\begin{abstract}
The article of S. Skvortsova "Teacher's methodical activity as a source of educational and methodical tasks", interprets the teacher's methodical activity as solving a number of methodical tasks. We define a methodical task as a situation that occurs in the process of teacher's methodical activity the purpose of which is to teach pupils certain content. Educational and methodical tasks are the models of such situations formulated in words. The goal of educational and methodical tasks is to form future teachers' methodical competency. Methodical tasks are classified under on practical and intellectual, that in its turn are divided into standard and problematic. Taking into consideration the external structure of the process of solving methodical tasks we define the teacher's ability to solve methodical tasks as a complex of actions to be performed to solve a methodical task on the basis of a teacher's conscious use of methodical knowledge and ways of action. Educational and methodical tasks are used in order to form the ability to solve methodical tasks in the process of teacher's methodical training in pedagogical universities. Educational and methodical tasks, as opposed to methodical tasks, are classified according to: 1) the level of methodical activity as on standard, partially-standard and creative; 2) the types of methodical activity as on informational-analytical, analytic-synthetic, operationally-practical, projectivemodeling, synthetic-constructing; 3) the content of teacher's methodical activity as on basic and special ones.

Standard and partially-standard educational and methodical tasks are the symbolic models of standard methodical tasks in teacher's activity, and creative educational and methodical tasks are the symbolic models of problematic methodical tasks. Educational and methodical tasks are mainly the models of intellectual methodical tasks as they don't suggest the interaction between a teacher and pupils, though, in some cases, they may be solved in the process of imitation of a teacher's activity in the classroom environment.
\end{abstract}

Keywords: teacher's methodical activity, methodical task, classification of methodical tasks, educational and methodical task, classification of educational and methodical tasks.

\section{INTRODUCTION}

The analysis of numerous publications about the quality of education in the world, suggests that school education needs reform and the introduction of innovative educational systems and approaches

\footnotetext{
${ }^{1}$ Translated from Journal Psychology and Special Education "Ion Creangă". State Pedagogical University. Psychology Special Pedagogy Social Work, 44 (3) (2016), 24-32. Available at: http://psihologie.upsc.md/current-issue-nr-44-3-2016/. Original article submitted June 20, 2016.
} 
to learning. A teacher is the driving force of educational reform, so the exit from the crisis is possible, by including improving the quality of teacher training in a pedagogical University.

The purpose of preparation of the teacher in pedagogical University is in the formation of his professional competence; meanwhile, the methodical competence of the teacher is a component of it (methodical competence of the teacher is one of its components). Such scientists as: B. Adolph, I. Akulenko, A. Kuz'minskii, N. Kuchugova, A. Larionova, A. Lebedeva, I. Malova, O. Matyas, V. Motorina, E. Scafa, N. Stefanova, N. Tarasenkova, L. Shkerina and others isolated the methodical competence of the teacher in the structure of professional competence.

It should be noted that a certain and generally accepted interpretation of this notion does not exist in the scientific literature, but the majority of researchers put in dependence the methodical competence of the teacher with the quality of his methodical activity (I. Akulenko, N. Gluzman, N. Kuzmina, A. Kuz'minskii, O. Matyas, T.Rudenko, N.Tarasenkova and others). However, the methodical competence of the teacher is considered as an expected result of his methodological preparation (O. Matyas), as integrated personal and professional characteristics of the teacher (N. Gluzman, N. Kuzmina, T. Mamontova, V. Shagan, etc.). A detailed analysis of scientific approaches to the interpretation of the notion of "methodical competence of the teacher" and its structure is presented in the author's works [1-3].

In our research, [4] we understand the methodical competence of the teacher as an integral personal education, which is manifested in the teacher's ability to effectively carry out methodical activities. Methodological activity, as a complex of functional and operational structure, includes implement a number of methodical actions by teacher. These actions are related with pupils' training, development and education in the process of mastering certain academic subject.

Based on the fact, that any human activity is appropriate to consider and design as a process of solving various problems (G. Ball, I. Lerner, A. Usova, N. Yakovleva), methodical activity of the teacher we are considering as a process of solving methodological problems. The methodical problem is interpreted as a situation, which arises in the course of methodical activity of the teacher. The purpose of which is to teach students a certain content considering their knowledge and skills. The teacher must follow methodological approaches to teaching the subject, means, forms and methods of teaching, etc. [5; 6]. A detailed analysis of the concept of "methodological task" is presented in the author's work from the point of view of problem setting, the general theory of solving problems [5].

Thus, the methodical competence of the teacher is a systematic and personal education, which manifested in the ability of teacher to solve methodological problems. Such problems are based on the theoretical and practical readiness of the teacher to perform professional functions in the field of study, development and education of pupils, in the learning process. Methodical competence of the teacher is an internal reserve of methodical competence, which defined requirements for the results of the methodological work of the teacher. Methodical knowledge and skills of the teacher, his orientations and experience of methodological work forms the basis of methodological competencies [7]. Methodological knowledge is the theoretical basis for the solution of methodical tasks. Methodical skills are understood as the ability to solve methodological tasks, based on the understanding of the methodical activities as the solution of the chain - the complex methodological tasks [4].

The purpose of this article is to present the author's classification of methodological tasks.

\section{Methodology AND Discussion}

Thus, methodical activities of the teacher provide the formulation and understanding of a methodical task by the teacher. Therefore the methodical task can't be considered in a separation from the teacher who solves it. Let's notice that in our research we distinguish methodical tasks as the situations arising in the process of methodical activity of the teacher. The goal of such tasks is to teach pupils of certain content. Also educational and methodical tasks we distinguish as, formulated verbally, models of such situations with the purpose of formation of methodical competence of future teachers. 
We classify methodical tasks on practical and, actually, cogitative tasks. Practical methodical tasks mean direct interaction of the teacher with the pupil, and actually cogitative tasks don't assume such interaction. Implementation of the teachers' functions is the result of the practical solutions of methodological problems. These functions are connected with teaching pupils certain content, controlling of pupils' achievements, the organization of certain types and forms of their activity, etc. Methodical concept, fact or method of activity is the result of the solution of actually cogitative methodical task as an element of methodical activity of the teacher.

Meanwhile, both practical and cogitative methodical tasks can be standard or problematic. The standard methodical task arises when the teacher used well-known ways of methodical activity to concrete methodical objects.

We consider a standard mental methodological problem when the teacher uses his well-known methods of methodical activity in the process of designing lesson. A process of the solution of a standard cogitative task assumes the following steps: 1) an analysis of the given situation, understanding by the teacher of conditions and requirements of the task; 2) actualization of relevant methodical knowledge and ways of activity; 3) their application to concrete methodical objects; 4) estimation of a possibility of satisfaction of requirements of a task.

The standard practical methodical task arises in the course of the lesson when the teacher realizes the ways of methodical activity simulated at a stage of preparation of a lesson. The process of the solution of a standard practical methodical task contains the following steps: 1) establishment of the correspondence between concrete practical and cogitative methodical task; 2) reproduction of the simulated method of the decision of the cogitative methodical task; 3) correlation of the result with the practical requirement of practical methodical problems; 4) the estimation of efficiency of the pedagogical impact directed to satisfaction of requirements of a task.

We can talk about a problematic methodical task if, solving a problematic or mental methodical task the teacher appears in the conditions of uncertainty, lack of the known models of methodical activities and forced to invent them. The receipt of a creative product such as a new methodical approach, a system of educational tasks and other, is a result of the solution of a problematic methodical task. In this case the problematic methodical task is in a fact a cogitative activity which doesn't assume an interaction with pupils. The problematic methodical task has a practical character when the adaptation of the known way of methodical activity to specific conditions of teaching is a result of her decision, according to the features of specific cognitive processes of certain pupils.

It should be noticed that the same methodological problem (thinking and practical) for one teacher may can be typical and for another - problematical. Accordingly, the problematic tasks can be the different level of problematical character: 1) tasks which solution algorithm is exist, but it is still not known to the teacher (such task stops being a problem for the teacher after its search and mastering); 2) tasks, algorithms which solutions exist, but of certain reasons don't satisfy the teacher, then he looks for an original way for the solution of this task; 3) tasks for which the way of the solution is still not known, for example, tasks of teaching certain content of the individual pupil or group of pupils, taking into account their specific features.

The process of the solution of problematic, actually, cogitative tasks, we represent as a complex of actions: 1) statement of a methodical task, formulation of her conditions and requirements; 2) mainstreaming of the known methodical concepts, facts and ways of activity; 3) their ratio with conditions and requirements of a task; 4) definition of expediency or inexpediency of complex use of the known methodical concepts, facts, ways of activity, based on conditions and requirements of a task; 5) stating the methodical idea (ways of the solution of a task); 6) modeling of a process of realization of the methodical idea - the invention of methodical approach, a system of educational tasks, etc.; 7) estimation of efficiency of developed methodical approach or system of educational tasks for satisfaction of requirements of a task; 8) correction of the developed methodical approach or system of educational tasks. The process can cyclically continue.

It should be noted that the standard cogitative methodical task is a basis for the solution of a standard practical methodical task. However, the problematic cogitative methodical task isn't a basis 
for the solution of a problematic practical task, because of having solved it in the process of cogitative activity, the teacher has already received a method of methodical activity. He needs to reproduce such algorithm in practice that doesn't assume problematic elements.

At the same time, the methodical activity of the teacher is full of problematical practical tasks, it's assuming a direct interaction with pupils. Such tasks arise spontaneously and require the instant solution considering specific conditions of education, features of concrete pupils or groups of pupils. In this case, the process of solving the problematic of practical methodical task includes the following steps: 1) updating of available methodical knowledge and methods of methodical activity; 2) estimation of opportunities of their use in a concrete situation, the choice of one or several methods of methodical activity; 3) the use of selected methods of methodical activity; 4) correlation of the received result with the fact that it was expected; 5) estimation of efficiency of the impact concerning satisfaction of the requirement of a methodical task; 6) definition of directions of the correction of a method of methodical activity and his improvement according to specific conditions; 7) use of the modified method of methodical activity, etc.

The process of solving methodical tasks can be represented as a composition of external and internal structure. The external structure of the process of the methodical tasks solution is described above through the complex of actions which performance can lead to the solution of a methodical task. Internal psychological structure of the process of solving methodical tasks is represented by means of cogitative operations which are carried out by the teacher in a process of the solution of a methodical task: analysis, synthesis, generalization, specification, classification, etc.

Exploring the external structure of a process of solving methodical tasks, we understand the quality of the teacher which is shown in ability consciously use the appropriated methodical knowledge and ways of activity in various conditions of pupils' education as ability of the teacher to solve methodical problems.

The structure is a complex skill, containing a set of actions: 1) definition of the purpose of a situation and conditions of its achievement: stating the problem and/or its analysis; 2) updating of theoretical data, known method to solve methodological: 3) its correlation with conditions and requirements of a task; 4) estimation of the received result from the point of view of satisfaction of a task's requirements; 5) correction of own methodical activity.

It should be noticed that we detail the concept "the ability to solve methodical problems" for different types of methodical tasks. We give definitions of different types of abilities of the solution of methodical tasks in work of the author [1], such as abilities to solve standard methodical problems (practical and cogitative) and abilities to solve problematic methodical problems (practical and cogitative), and also we distinguish their operational structure. We only note, that we understand the ways of methodical activity and operation with methodical objects acquired by the teacher which he freely uses in standard conditions of studying pupils as ability to solve standard methodical problems. We consider abilities to solve methodical problems in the conditions of uncertainty when in his arsenal there are no completely finished methods of methodical activities; as the ability to respond flexibly to changing conditions and to try to achieve an effective satisfaction of its requirements; as the ability to create a creative product.

The educational and methodical tasks (EMT) are used to form the ability to solve methodical problems in the course of methodical preparation the teacher in a pedagogical higher education institution. EMT examined by such scientists as O. Avtushko, I. Akulenko, O. Ayubova, O. Vodolazhenko, T. Demidova, Yu. Zayats, O. Igna, T. Kovtunova, O. Matyash, V. Motorina, O. Ovchinnikova, T. Smoleusova, etc. Methodical tasks are considered as specific carriers of content of education in the course of studying of future teachers (I. Akulenko, O. Matyash), as means of mastering methodical skills by future teachers (V. Motorina), the way of formation of methodical competence (O. Matyash); their appointment consists in technologization of methodical preparation, in optimization of mastering teaching skill, development of methodical thinking (O. Igna). It is possible to agree with definition of EMT given by the Ukrainian methodologist O. Matyash. The author considers them as tasks used in the course of methodical preparation of future teacher at the level of 
understanding, designing and practical implementation of methodical activities for the purpose of forming and developing of his methodical competence [8].

The analysis of the concept "methodical task" is given in O. Igna's work [9]. We support the author that in a source of methodical tasks it is impossible to consider only problematic situations arising in professional activity of a teacher, also it is wrong to say that all pedagogical activity of the teacher consists mainly of problems. We will note again, that in our research methodical tasks are considered as situations arising in the course of methodical activities. Their purpose consists in education of pupils of a certain content. Meanwhile educational and methodical tasks as verbally formulated models of such situations used for the formation of methodical competence of future teachers.

The analysis of the existing typologies of EMT of the Russian scientists represented in O. Igna's work [10], assures us that the existing classifications are specific and extremely diverse. They characterized by different degrees of a possibility of complex use, however they have the potential for application in various aspects of methodical preparation of the teacher. Deserve attention the classification by EMT Yu. Zayats, in which used two types of tasks for development of designing abilities of students: analytical and constructive. N. Yazykovaya selects three groups of methodical tasks in professional and methodical activity of the teacher: practical, technological and research, meanwhile each group of tasks is subdivided into subgroups. A. Kurashinova selected information and analytical, analytic-synthetic, design; organizational and preparatory; operational and practical tasks on the basis of the analysis of teacher's activity. T. Kovtunova classifies EMT by level of complexity (high, average, low).T. Mamontova groups EMT according to each level of activity such as: on reproductive the distinguishing, recognition, a remembering, correlation of a studying material executed by an example; on mandatory - the reproduction, correlation, understanding of more difficult studying material executed in a standard situation; tasks for transfer acquired in new conditions are offered in the level of possibilities, a reflection of educational and methodical activities, formation of methods of educational and methodical activities, tasks with creativity elements.

Ukrainian researchers comprehensively solve the problem of EMT classification. O. Matyash divides classes of tasks of methodical activities: strategic which are concretized in tactical tasks. It serves as a basis from which the author distinguishes criteria tasks and characterizes EMT [8].

Meanwhile, the relationship between tasks of methodical activity and EMT stayed out of the author's sight. This disadvantage was overcome by I. Akulenko who classified EMT based on the types of methodological activities and allocates tasks: modeling, design, analytical-synthetic and construction [11].

Considering the purpose of the solution of methodical task as formation of methodical abilities at future teachers, V. Motorina [12] classified EMT by certain bases. Such as the level of difficulty (simple and compound), according to contents (focused on assimilation by students of a course; the abilities which form at students the skill of organization of studying process; representing a combination of tasks of the first and second groups), by didactic purposes (developing, training, control), by types of thinking (in the process of the solution) (heuristic, algorithmic, semi-algorithmic).

The considered classifications were developed by authors, based on the goals of their research, and have both advantages and disadvantages. We support V. Motrina's and T. Mamontova's classifications, which is based on the type of thinking, and associated with him level of activity. Also I. Akulenko's and A. Kurashinova's classifications are interested to us. They based on types of methodical activities of the teacher.

In our research, we classified EMT by the level of methodical activities on standard, partiallystandard and creative [13], in contrast with properly methodical tasks. It is obvious that standard EMT assume recognition, reproduction, and usage of known to the student methodical facts and methods of activities in typical or standard situations, which are connected with pupils studying in a subject. Partially-standard EMT demands from the student the use of known methodical knowledge and methods of activities in specific-standard situation connected with teaching pupils in a subject. Let's note that a standard situation, arising in a process of teaching pupils a subject is different from specificstandard situation in what we assume reproduction of the methodical fact or use of the known method 
of activities without changes, in the form in which it was learned. Meanwhile, specific - a standard situation requires the use of a method of activities taking into account features of this situation. At the same time, standard MT is as a source of standard and partially-standard EMT. It should also be noted that partially-standard EMT also assume mastering a student the methodical fact and/or way of methodical activity, in the course of their solution.

EMT operate as a source of possible standard situations, which arise in the course of methodical activity of the teacher. These standard situations represent problems for students at first stages of mastering the methodical activity of the teacher. Therefore, partially-standard EMT are transformed into a standard in a process of mastering of methodical activity.

Creative EMT is connected with use of the methodical knowledge and abilities which are available for the student in the unusual situation, which arise in the course of studying pupils in a subject. Creative EMT operates as important models of MT problem.

It is possible to distinguish subtypes of EMT within the standard, partially-standard and creative EMT, if to classify by types of methodical activity, they are: information- analytic (tasks of search and studying of methodical information which is based on its analysis, selection of the main thing, etc.), analytic-synthetic (tasks of systematization of methodical concepts, the facts, methods of activities, etc.), operation-practical (tasks of mastering actions and transactions of methodical activities), modeling and design (a task of modeling the content of education, activities of the teacher and pupils at the lesson in general, on its particular stages, when studying certain elements of knowledge and methods of activities; tasks of designing of a lesson, its individual stages), construction (task of designing of system of educational tasks, innovative techniques, approaches, etc.). It is possible to allocate sub-classes of standard, partially-standard and creative tasks, proceeding from classification of EMT according to types of methodical activity (Tab. 1).

\begin{tabular}{|c|c|c|c|}
\hline & standard & partially-standard & creative \\
\hline information- analytic & + & & \\
\hline analytic -synthetic & & + & + \\
\hline operation-practical & + & + & + \\
\hline modeling and design & + & + & + \\
\hline construction & & & + \\
\hline
\end{tabular}

Tab. 1. Types of EMT.

Based on the content of methodical activities of the teacher, we classified EMT as basic and special. Basic EMT represents the situations which are a basis of methodical activities of the teacher. Such types of activity are: goal-setting, planning, design of a lesson or its stage, analysis of standard, educational and education-methodical literature. So, the teacher can't perform the activities without setting the goals and a task of the study section, a theme, etc. That is why he shall learn to solve EMT according to stating of the purposes and tasks of the section, a subject, specific lesson, by the basis of knowledge of the regulating documents (State Standard, training programs). Such documents regulate the content of education and its results. Education of the subject is performed with use of a certain textbook, a notebook with a printing basis, that is why the teacher must learn how to solve EMT, which are connected with the analysis of educational and methodical sets and determinations of the set allowing to optimally realize content and requirements of the program. Basic EMT also concern the development of calendar and thematic planning of lessons, the analysis and use of various forms, methods, means and technologies of training at separate stages of a lesson.

Standard, variable, control-estimating, technological, projective-modeling competencies are formed by means of basic EMT, which constitute the methodical competence of the teacher.

Plots of special EMT assume the consideration of the situations concerning teaching pupils in a certain question of the program, different stages of a lesson (actualization of basic knowledge and methods of action, acquaintance with new knowledge and methods of action, forming of skills). 
The purpose of solution special EMT is implementation of methods of studying certain questions of the program. That includes their revisions for a particular textbook, in order to reach the state requirements to the level of general education of pupils. By means of special EMT we can perform the formation of special-methodical competence. It should be noticed, that basic and special EMT can be standard, partially-standard and creative.

\section{CONCLUSIONS}

Thus, methodical activity of the teacher can be presented as a chain of solution of methodical tasks. We consider methodical tasks as the situations arising in the course of methodical activity of the teacher which purpose is training school students in a certain contents, and educational and methodical tasks as, being formulated verbally, models of such situations with the purpose of forming methodical competence of future teachers.

We classify methodical tasks as practical and, actually, cogitative, which can be standard or problematic. Process of solution of methodical tasks can be presented as composition of external and internal structure. The external structure of the process of solution of methodical tasks is represented through a complex of actions which performance can lead to the solution of a methodical task. Exploring external structure of process of the methodical tasks solution, we gave a definition of ability of the teacher to solve methodical tasks through a complex of actions, which need to be performed to solve a methodical task on the basis of conscious use of the methodical knowledge and ways of activity, appropriated by the teacher. For the formation of ability to solve methodical tasks in the course of methodical training of the teacher in pedagogical university the educational and methodical tasks (EMT) are used. In our research EMT, not like actually methodical tasks, EMT we classified by the level of methodical activity as standard, partially-standard and creative; according to the types of methodical activity, as: information - analytic, analytic - synthetic, operational - practical, modeling and design, construction; proceeding from the content of methodical activity of the teacher, as basic and special.

Standard and partly-standard EMT are iconic models of standard methodical tasks in the teacher's activity, and creative EMT - iconic models of problematic methodical tasks. EMT, generally there are models of cogitative methodical tasks as they don't assume interaction of the teacher with pupils, though can be solved in certain cases in the course of imitation of activity of the teacher in classroom conditions.

\section{REFERENCES}

[1] Skvortsova S.O., Haievets Ya.S. Preparing of future elementary school teachers for teaching younger schoolchildren to solve narrative mathematical problems. Ranok - NT, Kharkiv, 2013. (in Ukrainian)

[2] Skvortsova S.O. Ways of formation the professional competence of future teachers. In: Proc of the Intern. Conf. "The integration of general and professional mathematical education of countries of the European community in the context of the Bologna agreement", Bryansk, Russia, 2014, Izd-vo OOO "Ladomir", Bryansk, 2014, 192-202. (in Russian)

[3] Skvortsova S.O. Methodical competency of primary school teachers. In: Ostenda A., Nestorenko T. (Eds.) Information and technologies in the development of socio-economic systems: Series of monographs Faculty of Architecture, Civil Engineering and Applied Arts Katowice School of Technology, 55-63. Publisher of the Higher Technical School in Katowice, Katowice, 2016. (in Polish)

[4] Skvortsova S.O. Abilities to solve methodological problems as internal reserve methodological competence of teachers. Scientific Journal "ScienceRise" Pedagogical Education, 3/5 (20) (2016), 54-58. (in Ukrainian) 
[5] Skvortsova S.O. Methodical task in the context of teacher's activity. Perspective ways of scientifical researches, 45-46. Tsentr navchalnoi literatury, Kyiv, 2015. (in Ukrainian)

[6] Skvortsova S.O. Methodical task and educational-methodical task: concepts and correlation. In: Economics, management, law: problems of establishing and transformation, 398-401. Al-Ghurair Printing and Publishing LLC, Dubai, UAE, 2016.

[7] Skvortsova S.O. The formation of methodical competence of future teachers by means of studying discipline "Methods of teaching mathematics". Journal Psychology and Special Education "Ion Creangă". State Pedagogical University. Psychology Special Pedagogy Social Work, 3 (40) (2015), 24-32. (in Russian)

[8] Matyash O.I. Theoretical and methodological principles of formation of methodical competence of the future mathematics teacher to study geometry. TOV “Nilan-LTD”, Vinnytsia, 2013. (in Ukrainian)

[9] Igna O.N. Methodological tasks in professional preparing of the teacher: the content and classification. Vestnic TSPU, 7 (85) (2009), 20-25. (in Russian)

[10] Igna O.N. Modern classification of educational methodological problems. Psychology and Pedagogy, 11 (2009), 177-182. (in Russian)

[11] Akulenko I.A. Competence oriented on the methodical preparation of the future mathematics teacher of specialized schools (theoretical aspect). Publisher Chabanenko Yu., Cherkasy, 2013. (in Ukrainian)

[12] Vodolazhenko O.V., Motorina V.G. The solving of methodical problems as a way of formation the methodical competence of future mathematics teachers. Science and Education a New Dimension: Pedagogy and Psychology, 7 (2013), 41-50. (in Ukrainian)

[13] Skvortsova S.O. Educational and methodical tasks as ways of formation the methodical competence of future mathematics teachers. Collection of scientific works by materials of the International science practical conference, November 26-27, 2015, Planer, Vinnytsia, 48-50. (in Ukrainian)

Address: Svitlana Skvortsova, South Ukrainian National Pedagogical University named after K. D. Ushynsky, 26, Staroportofrankivs'ka Str., Odesa, 65020, Ukraine.

E-mail: skvo08@i.ua.

Received: 24.11.2017; revised: 05.03.2018.

Скворцова Світлана. Методична діяльність учителя як основа вирішення навчально-методичних завдань. Журнал Прикарпатського університету імені Василя Стефаника, 5 (1) (2018), 31-39.

У статті представлено методичну діяльність учителя як ланцюжок рішення методичних завдань. Методичні завдання (МО3) визначено як ситуації, що виникають у процесі методичної діяльності педагога, метою яких є навчання школярів певного змісту, відповідно навчально-методичні завдання (УМЗ) - сформульовані словесно моделі таких ситуацій для формування методичної компетентності майбутніх учителів.

Автором подано класифікацію методичних завдань: практичні i, власне, розумові, які своєю чергою поділяють на стандартні і проблемні. Досліджуючи зовнішню структуру процесу вирішення методичних завдань, представлено визначення вміння вчителя вирішувати методичні завдання через комплекс дій, які необхідно виконати, щоб вирішити методичну задачу на основі усвідомленого використання здобутих учителем методичних знань і способів діяльності. Для формування вміння вирішувати методичні завдання в процесі методичної підготовки вчителя в педагогічному вищому навчальному закладі використано навчально-методичні завдання (УМЗ). У УМЗ, на відміну від власне методичних завдань, класифікують: 1) за рівнем методичної діяльності: стандартні, частковостандартні і творчі; 2) відповідно до видів методичної діядьності: інформаційно-аналітичні, аналітикосинтетичні, операційно-практичні, проективно-моделювальні, синтетико-конструювальні; 3) виходячи зі змісту методичної діяльності вчителя: базові та спеціальні. Доведено, що стандартні і частково-стандартні УМЗ є знаковими моделями стандартних методичних завдань у діяльності 
педагога, а творчі УМЗ - знаковими моделями проблемних методичних завдань. Обгрунтовано, що УМЗ, в основному, є моделями розумових методичних завдань, оскідьки вони не передбачають взаємодіі вчителя з учнями, хоча, в деяких випадках можуть бути вирішені в процесі імітації діяльності вчителя в аудиторних умовах.

Ключові слова: методична діяльність вчителя, методична задача, класифікація методичних завдань, навчально-методична задача, класифікація навчально-методичних завдань. 